Europe's Journal of Psychology, 6(3), pp. 1-8

www.ejop.org

\title{
Introductory Comments: Special Issue of EJOP (August 2010) on Humor Research in Personality and Social Psychology
}

\author{
Nicholas A. Kuiper \\ Guest Editor, Special Humor Issue of EJOP \\ Univ ersity of Western Ontario
}

Welcome to this special humor issue of Europe's Journal of Psychology. This August 2010 EJOP issue is devoted to a presentation of contemporary psychological research on humor, with a particular emphasis on work that targets the personality and social aspects of humor, including stress, coping and well-being.

This special issue can be placed into a broader context by noting that we are currently enjoying a psychological renaissance in research on humor. Each year, an increasing number of scientific articles are being published about the psychological aspects of humor. This is clearly seen in Table 1, which provides one rough index of humor publications in psychology over the past thirty years. This was done by searching in PsychINFO, using the term "humor," across a sequence of one-year time periods (beginning in 1980), and then advancing in five year increments. Thus,

$\begin{array}{ccc}\text { Year of } & \begin{array}{c}\text { Peer-Reviewed } \\ \text { Journals }\end{array} & \begin{array}{c}\text { Total Published } \\ \text { Works }\end{array} \\ 1980 & 25 & 47 \\ 1985 & 58 & 97 \\ 1990 & 81 & 140 \\ 1995 & 88 & 119 \\ 2000 & 136 & 218 \\ 2005 & 345 & 461 \\ 2009 & 377 & 519\end{array}$

Table 1: Number of Humor Publications in Psychology 1980-2009 
starting in 1980, there was a grand total of 47 publications on psychological aspects of humor in all of that year, with 25 of these being in peer-reviewed journals. Moving forward, we begin to see a slow but steady increase in humor research, reaching an overall total of 119 works published in 1995, with the majority of these now in peerreviewed sources (88).

What is truly remarkable is what has happened to this field since 1995. As we enter the new millennium, the total number of published works on humor has almost doubled to 218 for the year 2000. This doubling continues unabated in the next time period sampled (2005), with a total of 461 publications, of which the majority are in peer-reviewed journals (345). Finally, evidence from the most recent one year period available (2009) indicates that this interest in the psychological investigation of humor still continues at a high rate of enthusiasm, with the total number of published works now above 500, and peer-reviewed publications forming almost three-quarters of this total (377).

Given this recent exponential growth in psychological research on humor, it seemed both timely and appropriate to put together a special issue that would showcase some of this work. The goal here was not to offer a comprehensive overview of all of the psychological work on humor (for this, see Martin, 2007); but rather, to offer a snapshot of several contemporary personality and social psychology approaches to humor. This was done by approaching a number of prominent humor investigators in several different countries (Canada, United States, Great Britain, Belgium, Norway and Lebanon); and then asking them to provide a sample of their work that would be suitable for a special EJOP issue focusing on personality and social psychological approaches to humor. The responses were extremely gratifying, and ultimately resulted in the production of this special humor issue. The entire list of contributors to this special issue, and the titles of their articles are shown in Table 2.

\footnotetext{
Europe's Journal of Psychology (EJOP) - August 2010 Humor Research in Personality and Social Psychology Special Humor Issue Editor: Nicholas A. Kuiper, Ph.D.
}

Kuiper, Nicholas A. Introductory comments: Special Issue of EJOP on Humor Research in Personality and Social Psychology.

Veselka, Livia, Schermer, Julie A., Martin, Rod A., Cherkas, Lynn F., Spector, Tim D. \& Vernon, Tony A. A Behavioral Genetic Study of Relationships between Humor Styles and the Six HEXACO Personality Factors. 
Hampes, William, P. The Relation between Humor and Empathy.

Janes, Leslie M. \& Olson, James M. Is it You or is it Me? Contrasting Effects of Ridicule Targeting Other People Versus the Self.

Kazarian, Shahe S., Moghnie, Lamia, \& Martin, Rod A. Perceived Parental Warmth and Rejection in Childhood as Predictors of Humor Styles and Subjective Happiness.

Saroglou, Vassilis, Lacour, Christelle \& Demeure, Marie-Eve. Bad Humor, Bad Marriage: Humor Styles in Divorced and Married Couples.

Freeman, Gillian P. \& Ventis, W. Larry. Does Humor Benefit Health in Retirement? Exploring Humor as a Moderator.

Kuiper, Nicholas A., Kazarian, Shahe S., Sine, Jessica \& Bassil, Margaret. The Impact of Humor in North American versus Middle East Cultures

Woodzicka, Julie A. \& Ford, Thomas E. A Framework for Thinking about the (not-sofunny) Effects of Sexist Humor.

Edwards, Kim R. \& Martin, Rod A. Humor Creation Ability and Mental Health: Are Funny People more Psychologically Healthy?

Cann, Arnie, Stilwell, Kelly \& Taku, Kanako. Humor Styles, Positive Personality and Health.

Kuiper, Nicholas A., Kirsh, Gillian A., \& Leite, Catherine. Reactions to Humorous Comments and Implicit Theories of Humor Styles.

Beins, Bernard C. \& O'Toole, Shawn M. Se arching for the Sense of Humor: Stereotypes of Ourselves and Others.

Svebak, Sven. The Sense of Humor Questionnaire: Conceptualization and Review of 40 Years of Findings in Empirical Research.

Table 2: List of Contributors \& Article Titles for Special Humor Issue of EJOP 
Even a cursory examination of the titles shown in Table 2 indicates the wide range of issues that are currently being investigated by this group of humor researchers. As can be seen from this Table, and also as shown separately in Table 3 for each article, these topics and issues range from behavioral genetic analyses of humor and personality to the negative effects of certain types of humor on various relationships and societal norms. Also of interest are the moderating and mediating effects of humor on stress, coping and health, along with the social and interpersonal effects of humor. These investigators are also busy mapping out humor stereotypes and implicit theories of humor used for self and others. Furthermore, the links between sense of humor and other positive personality factors are also being considered, along with work focusing on measures of humor creativity. Finally, some of the work reported in this special EJOP issue addresses developmental factors that link childhood upbringing with certain humor styles; whereas other research reported here considers the cross-cultural similarities and differences in the effects of humor on social and personal relationships. Overall, there certainly is a broad range of topics and issues being examined in this special issue; and this clearly reinforces the notion that we are in the midst of a renaissance of humor knowledge and investigation.

In addition to presenting an overview of the main issues examined in each of the articles in this special issue, Table 3 also provides a brief summary of the type of humor considered in each article, and the samples that were employed. As can be seen in Table 3, the samples in the various studies come from a wide variety of different countries, and include not only university undergraduate students,

\begin{tabular}{|c|c|c|c|}
\hline Investigat ors & Humor & Sample & Main Issues Examined \\
\hline \multirow[t]{7}{*}{ Veselka et al. } & 4 Humor Styles & Twins (MZ \&DZ) & Situate Humor Styles in \\
\hline & Affiliative & Great Britain & Hexaco Personality \\
\hline & Self-enhancing & & Model (6 factors) \\
\hline & Aggressive & & \\
\hline & Self-defeating & & Behavioral Genetic \\
\hline & & & Analysis of Humor \\
\hline & & & Styles \& Personality \\
\hline \multirow[t]{3}{*}{ Hampes } & 4 Humor Styles & Undergrads & Relationships Between \\
\hline & & United States & Humor Style and Various \\
\hline & & & Components of Empathy \\
\hline
\end{tabular}


Janes \&

Olson

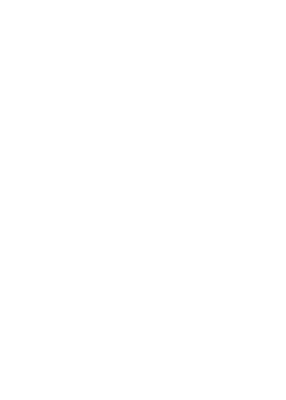

Kazarian et al.

4 Humor Styles

Undergrads

Lebanon

Saroglou et al.

\begin{abstract}
4 Humor Styles
(early v ariants)

Earthy Humor
\end{abstract}

Married \&

Div orced

Couples

Belgium

Canada

Review Major Theories of

Disparagement Humor

\section{Effects of Disparagement Humor on Conformity, Fear \\ of Failure, and Creativity \\ Differential Effects for Self \\ Versus Other Ridicule}

\author{
Relationships of Humor \\ Styles with Parental \\ Acceptance \& Rejection \\ Explore how Humor Styles \\ Mediate Relationships \\ Between Parental Warmth \\ or Rejection \& Happiness
}

Impact of Humor Styles on

Relationship Quality in both

Married \&Divorced Couples

Humor Styles Predicting

Div orce beyond

Attachment Indices

Partner Similarity in Humor

Styles \& Impact on Marriage

Retirees over Stress-Moderating Role of

the age of $55 \quad$ Humor Styles in Retirement

United States

Specificity of Adaptive versus

Maladaptive Nature

of each Humor Style

Kuiper, Kazarian 4 Humor Styles

Undergrads

Impact of Humor Styles on

et al.
Canada \&

Lebanon
Others, including Cross-

Cultural Differences 


\begin{tabular}{|c|c|c|c|}
\hline $\begin{array}{l}\text { Woodzicka \& } \\
\text { Ford }\end{array}$ & $\begin{array}{l}\text { Sexist Humor } \\
\text { (Hostile \& } \\
\text { Benevolent) }\end{array}$ & $\begin{array}{l}\text { Various Samples } \\
\text { in Review } \\
\text { United States } \\
\text { \& Elsewhere }\end{array}$ & $\begin{array}{l}\text { Direct \&Indirect Negative } \\
\text { Effects of Sexist Humor } \\
\text { Review Theories of Sexist } \\
\text { Humor \& Indicate Future } \\
\text { Research Directions }\end{array}$ \\
\hline $\begin{array}{l}\text { Edwards \& } \\
\text { Martin }\end{array}$ & $\begin{array}{l}4 \text { Humor Styles \& } \\
\text { Humor Creation } \\
\text { Ability ( } 2 \text { measures) }\end{array}$ & $\begin{array}{l}\text { Undergrads } \\
\text { Canada }\end{array}$ & $\begin{array}{l}\text { Relationships between } \\
\text { Humor Styles, Humor } \\
\text { Creativity \& Psychological } \\
\text { Well-being }\end{array}$ \\
\hline Cann et al., & 4 Humor Styles & $\begin{array}{l}\text { Undergrads } \\
\text { United States }\end{array}$ & $\begin{array}{l}\text { Humor Styles as Mediators } \\
\text { of Stress-Reduction for } \\
\text { Physical \& Mental Health }\end{array}$ \\
\hline $\begin{array}{l}\text { Kuiper, Kirsh \& } \\
\text { Leite }\end{array}$ & 4 Humor Styles & $\begin{array}{l}\text { Undergrads \& } \\
\text { High School } \\
\text { Adolescents } \\
\text { Canada }\end{array}$ & $\begin{array}{l}\text { Impact of Humor Styles on } \\
\text { Others \& Social Relations } \\
\text { Implicit Theories of Humor } \\
\text { Styles for Self \& Others }\end{array}$ \\
\hline Beins \& O'Toole & $\begin{array}{l}\text { Multidimensional } \\
\text { Sense of Humor } \\
\text { (Humor Production, } \\
\text { Attitudes tow ards } \\
\text { Humor Use, Coping } \\
\text { Humor, \& Humor } \\
\text { Appreciation) }\end{array}$ & $\begin{array}{l}\text { Undergrads } \\
\text { United States }\end{array}$ & $\begin{array}{l}\text { Match between Self- } \\
\text { Reports of Humor \& } \\
\text { Other Measures of } \\
\text { Sense of Humor } \\
\text { Humor Level \& } \\
\text { Personality Attributions } \\
\text { for Self \&Others }\end{array}$ \\
\hline Svebak & $\begin{array}{l}\text { Sense of Humor } \\
\text { Questionnaire } \\
\text { \&Variants (SHQ-6) }\end{array}$ & $\begin{array}{l}\text { Various Samples } \\
\text { in Review } \\
\text { Norway \& } \\
\text { Elsewhere }\end{array}$ & $\begin{array}{l}\text { Development of SHQ } \\
\text { and Subsequent Variants } \\
\text { Review Major Findings of } \\
\text { Wide Variety of Empirical } \\
\text { Studies using SHQ }\end{array}$ \\
\hline
\end{tabular}

Table 3: Overview of the Articles in the Special Humor Issue of EJOP 
but also married and divorced couples, monozygotic (MZ) and dizygotic (DZ) twins, retirees, adolescents, and community-based participants. This breadth of participant characteristics is impressive, and indicates the extent to which the investigators in this special issue have already begun to consider the application of contemporary humor theory and research to diverse groups and populations.

In terms of defining humor, Table 3 illustrates that a variety of different approaches are represented in this special issue, with several of the studies examining the four humor styles described by Rod Martin and his colleagues. These styles include two adaptive forms of humor (self-enhancing and affiliative) and two maladaptive forms (self-defeating and aggressive). This multi-faceted approach to considering sense of humor provides for a rigorous examination of not only the potential benefits associated with humor, but also the detrimental effects which may accrue. Of further interest are other approaches to the construct of humor, as exemplified by the articles focusing on disparagement humor (ridicule), sexist humor, and humor creativity. Additional approaches to defining humor are evident in the articles examining the Sense of Humor Questionnaire and the Multidimensional Sense of Humor Measure. Both of these measures further illustrate the complexity of humor, as several different humor facets are identified, including humor production, attitudes towards the use of humor, coping humor, humor appreciation, liking of humorous situations, and meta-message sensitivity.

When taken together, the various approaches to sense of humor represented in this special issue clearly illustrate two major points. The first is that sense of humor must be respected as a very complex phenomenon that any single humor measure will never successfully encompass. Secondly, much more research and theorizing is necessary in terms of clearly articulating the various facets of sense of humor. While measures such as the Humor Styles Questionnaire (HSQ) and Sense of Humor Questionnaire (SHQ) have both provided considerable clarification in terms of measuring the various facets of sense of humor, further work is still required.

\section{Concluding Comments}

As you read through the articles presented in this special humor issue of EJOP, I hope you find them to be informative and enlightening, and perhaps spark an interest in research studies that you may now wish to conduct in the humor domain. It is also important to reiterate once more that this special issue provides a snapshot of several contemporary approaches to humor research with a personality and social psychologic al flavour, and thus should not be taken as an exhaustive examination of 
all the different approaches to the psychological investigation of humor. There are other models and approaches that have not been represented in this special issue, but also warrant full consideration as the field progresses and mature.

Finally, I would like to thank all of the contributors to this special issue for their assistance, patience, and co-operation throughout the entire editorial process. The contributors were extremely responsive to the various publication deadlines, and as such, made my job as the editor of this special issue just a little bit easier! Last, but not least, I would like to offer considerable thanks to the chief editor of EJOP, VIad Glăveanu, who has fully supported and assisted me with this project from the outset.

\section{Reference}

Martin, R. A. (2007). The psychology of humor: An integrative approach. New York: Academic Press.

\section{About the author:}

Nicholas A. Kuiper has been a professor of psychology for over 32 years at the University of Western Ontario in London, Ontario, Canada. His interest in studying the psychology of humor began in the early 1990's, with a special emphasis on the personality and social psychological aspects of humor. Much of his research has focused on individual differences in sense of humor, with implications for stress, coping, psychological well-being, physical health, and other positive and negative emotions. Further research has examined humor use in romantic relationships and the potential links between humor use and bullying in middle childhood.

Address for correspondence: N. Kuiper, Department of Psychology, Westminster Hall, Univ ersity of Western Ontario, London, Ontario, Canada N6A 3K7

E-mail: kuiper@uwo.ca 